\title{
GANGGUAN PENDENGARAN PADA PEKERJA DI TEMPAT HIBURAN MALAM DI KOTA MANADO
}

\author{
${ }^{1}$ Hanry Junianto \\ ${ }^{2}$ Maya Moningka \\ ${ }^{2}$ Jimmy Rumampuk
}

\begin{abstract}
Kandidat Skripsi Fakultas Kedokteran Universitas Sam Ratulangi Manado
Bagian Fisika Fakultas Kedokteran Universitas Sam Ratulangi Manado

Email: hareeyhalim@gmail.com
\end{abstract}

\begin{abstract}
Abstrak. Gangguan pendengaran akibat kebisingan, adalah gangguan pendengaran baik sebagian atau seluruh pendengaran, bersifat menetap, terjadi pada satu atau dua telinga, dapat bersifat ringan, sedang atau berat, terjadi karena paparan bising yang terus-menerus dari lingkungan. Gangguan pendengaran akibat kebisingan bervariasi diantara individu. Tujuan khusus penelitian ini adalah untuk mengetahui intensitas kebisingan pada tempat kerja (diskotik) yang dapat menyebabkan gangguan pendengaran. Penelitian ini merupakan jenis penelitian deskriptif dengan menggunakan pendekatan secara cross sectional. Hasil penelitian ini terdapat gangguan pendengaran sebesar $40 \%$. Mulai dari gangguan pendengaran ringan $35 \%$ dan gangguan pendengaran sedang 5\%, dapat di simpulkan bahwa bekerja di lingkungan yang berintensitas bising tinggi dapat menpengaruhi fungsi pendengaran, sehingga di butuhkan penyuluhan dan sosialisasi kepada pekerja di tempat hiburan malam agar mereka mengtahui tentang gangguan pendengaran akibat kebisingan.
\end{abstract}

Kata Kunci: Bising, Fungsi Pendengaran, Pekerja hiburan malam di SCORE manado, Keselamatan kerja.

Abstract. Noise-induced hearing loss, hearing loss is either a part or the whole hearing, irreversible, occurs in one or both ears, can be mild, moderate or severe, occurs because of exposure to continuous noise from the environment. Noise-induced hearing loss varies among individuals. The specific objective of this study was to determine the intensity of noise in the workplace ( discotheque ), which can cause hearing loss . This research is a descriptive study using cross sectional approach. The results of this study are of hearing loss by $40 \%$. Ranging from mild hearing loss and hearing loss $35 \%$ was $5 \%$, it can be concluded that working in an environment of high -intensity noise can affect auditory function, so in need of extension and outreach to workers in nightclubs so they know about noise-induced hearing loss.

Keywords : Noise, Hearing Function, SCORE Workers nightclub in Manado, Safety work.

Bising di tempat kerja merupakan masalah utama dalam kesehatan kerja di berbagai negara. Diperkirakan sedikitnya 7 juta orang (35\% dari total populasi) terpajan dengan bising $>85$ dBA. Ketulian yang terjadi dalam industri menduduki urutan pertama dalam daftar penyakit Kelompok tenaga kerja yang terpajan bising selama kerja memperlihatkan ketulian $>20 \%$. $^{1,2}$

Noise Induce Hearing Loss (NIHL) atau gangguan pendengaran akibat kebisingan, adalah gangguan pendengaran baik sebagian atau seluruh pendengaran, bersifat menetap, terpadi pada satu atau dua telinga, 
dapat bersifat ringan, sedang, berat, terjadi karena paparan bising yang terus-menerus dari lingkungan. ${ }^{1,2,3}$

Penurunan sensivitas pendengaran, seringkali di sebut notch, pada konfigurasi audiometrik antara 3000-6000 Hz, di kenal sebagai Noice Induce Hearing Loss (NIHL). Penurunan pendengaran adalah proses berangsur-angsur yang tidak di sadari selama bertahun-tahun. Bila gangguan pendengaran terjadi, penderita secara umum mengeluh tidak dapat mengikuti percakapan dan tidak jelas. Paparan bising seringkali diabaikan, tapi tidak disadari bahwa sumber potential trauma akustik kadang terjadi pada tempat biasa dikunjungi. ${ }^{3,5}$

Gangguan pendengaran yang tidak di tangani memiliki efek negatif psikologi serius pada pekerja yang selalu terpapar bising. Efek psikologi yang dapat timbul seperti, rasa malu, rasa bersalah dan marah, perasaan di permalukan, masalah konsentrasi, merasa tidak aman, rasa rendah diri/rasa percaya diri kurang. ${ }^{6,7}$

Menurut Occupational Safety and Health Administration (OSHA), 5-10 juta orang Amerika dapat beresiko mendapat gangguan pendengaran atau di sebut Noice Induce Hearing Loss (NIHL), karena mereka terpapar bunyi dengan kekuatan lebih dari 85 dBA pada tempat kerja dengan waktu yang lama dan secara terus menerus. ${ }^{1}$ Lebih banyak pria yang mengalami gangguan pendengaran di bandingkan wanita, akan tetapi, akibat dari intensivitas terhadap NIHL, lebih besar di tempat kerja atau apakah ini menggambarkan paparan level yang tinggi pada tempat lain, masih belum jelas. ${ }^{1}$

Tipe-tipe gangguan pendengaran ada 3 macam yaitu, Tuli konduktif ( Conductive hearing loss ) terjadi dari apapun yang dapat menyebabkan penurunan transmisi suara dari luar ke koklea. Penyebabnya termasuk pembentukan abnormal dari aurikula atau heliks, serumen dalam kanal telinga, efusi telingah tengah, atau disfungsi atau fiksasi dari rangkaian osikular. Salah satu contohnya adalah otosklerosis.
Tuli saraf/persepi (Sensori Neural Hearing Loss ), dapat terjadi dari gangguan transmisi sesudah koklea. Gangguan transmisi ini dapat terjadi karena kerusakan hair cell dalam koklea atau kerusakan nervus cranial. ${ }^{11}$ Tuli campuran (Conductive Hearing Loss) dan (Sensori Neural Hearing Loss).

Gangguan pendengaran ( Noice Induce Hearing Loss ) akibat pekerjaan adalah hilangnya fungsi pendengaran akibat paparan kebisingan yang berkelanjutan dan intermiten serta durasi lama dan biasanya berkembang lambat sampai beberapa tahun. ${ }^{4}$ Paparan kebisingan di ukur berdasarkan sumber kekuatan suara dalam satuan Decibel ( $\mathrm{dB}$ ) yang merupakan satuan untuk pengukuran level suara. Paparan akibat kebisingan dapat menyebabkan, penurunan pendengaran secara berangsur-angsur melalui periode waktu atau begitu kuatnya sehingga bisa menyebabkan kehilangan pendengaran. ${ }^{1,8}$

Noice Induce Hearing Loss (NIHL) lebih banyak mengalami masalah serius yang di derita oleh banyak orang karena beberapa alasan, ancaman kehilangan pekerjaan dapat memaksa seseorang untuk tetap pada lingkungan bising yang tidak dapat mereka toleransi, dan di tempat kerja, kebisingan dengan level yang tinggi, di alami terus-menerus setiap hari sampai beberapa tahun. ${ }^{9,10}$

Telah diketahui dengam baik bahwa paparan terhadap level suara yang tinggi untuk periode waktu yang lama merupakan kontributor utama gangguan pendengaran. ${ }^{13}$ Kebanyakan seseorang yang terpajan pada kebisingan jangka lama, yang mungkin intermiten atau terus menerus. Transmisi energi seperti itu, jika cukup lama dan kuat akan merusak organ korti dan selanjutya mengakibatkan ketulian permanen. 9,10

\section{METODE PENELITIAN}

Penelitian ini merupakan jenis penelitian yang bersifat deskriptif dengan melakukan pendekatan secara cross sectional. Penelitian ini di laksanakan pada 
pekerja hiburan malam SCORE di Kota Manado, Sulawesi Utara. Populasi dan sampel di ambil berdasarkan total sampling yaitu 20 sampel, Kriteria inklusinya yaitu pekerja hiburan malam sebagai Disc Jockey (DJ), bartender, pelayan minuman. Bersedia untuk mengisi informed consent.

Alat dan bahan penelitian berupa, alat tulis menulis, sound level meter, audiometri, kuisioner. Cara pengumpulan data meliputi:

i. Data primer di peroleh dari pengukuran kebisingan diskotik.

ii. Pemeriksaan daya dengar pekerja diskotik.

iii. Pengumpulan data kuesioner.

Prosedur penelitian di lakukan 2 tahap yaitu, tahap persiapan dan tahap pelaksanaan :

1. Tahap persiapan

a. Di lakukan sosialisasi dampak kebisingan pada pekerja diskotik.

b. Penandatangan informed consent yang setuju dan memenuhi syarat.

c. Wawancara kuisioner oleh responden.

2. Tahap pelaksanaan

a. Pemeriksaan intensitas bising diskotik dengan menggunakan alat Sound Level Meter.

b. Pengukuran audiometri pada responden di lakukan tes gangguan pendengaran di ruang THT RSUP. Prof Kandou Malalayang dengan menggunakan menggunakan alat tes audiometer.

Pengumpulan data di lakukan dengan mengumpulkan kuisioner dan data di olah dengan microsoft excel berdasarkan variabel penelitian dan di sajikan dalam bentuk tabel distribusi.

\section{HASIL PENELITIAN PEMBAHASAN}

DAN

Penelitian di lakukan pada 20 pekerja hiburan malam di SCORE manado. Sampel penelitian berjenis kelamin laki-laki sebanyak 16 sampel, dan sampel berjenis kelamin perempuan sebanyak 4 sampel.

1. Gambaran sampel:

Hasil audiometri berdasarkan berat ringannya gangguan pendengaran pada pekerja hiburan malam di tunjukan oleh Tabel 1.

Tabel 1. Hasil audiometri berdasarkan berat ringannya gangguan pendengaran pada pekerja hiburan malam.

\begin{tabular}{lll}
\hline \multirow{2}{*}{$\begin{array}{l}\text { Gangguan } \\
\text { pendengaran }\end{array}$} & \multicolumn{2}{l}{ Hasil audiometri } \\
\cline { 2 - 3 } Normal & 12 & $\mathbf{\%}$ \\
\hline Tuli ringan & 7 & 60 \\
Tuli sedang & 1 & 35 \\
Tuli berat & - & 5 \\
\hline Total & $\mathbf{2 0}$ & - \\
\hline
\end{tabular}

Pada penelitian ini paling banyak terjadi adalah tuli ringan. Bila melihat pada tingkat kebisingan yang rata-rata lebih tinggi di atas tingkat kebisingan tempat kerja lain, gangguan pendengaran mungkin akan lebih berat di alami oleh pekerja hiburan hiburan malam. Namun pada data ini gangguan pendengaran yang terjadi lebih ringan namun kebanyakan simetrik.

Hasil audiometri berdasarkan jenis ketulian di tunjukan oleh tabel 2.

Tabel 2. Hasil audiometri berdasarkan jenis ketulian.

\begin{tabular}{lcc}
\hline \multirow{2}{*}{ Jenis Ketulian } & \multicolumn{2}{c}{ Hasil audiometri } \\
\cline { 2 - 3 } & $\mathbf{n}$ & $\mathbf{\%}$ \\
\hline Normal & 11 & 55 \\
Tuli konduktif & 7 & 35 \\
Tuli & 1 & 5 \\
sensorineural & 1 & 5 \\
Tuli campuran & & \\
\hline Total & $\mathbf{2 0}$ & $\mathbf{1 0 0} \%$ \\
\hline
\end{tabular}

Setelah di lakukan pemeriksaan fungsi pendengaran terdapat 11 responden yang fungsi pendengarannya masih normal, 7 responden mengalami tuli konduktif, 1 
responden mengalami tuli sensorineural dan 1 responden mengalami tuli campuran.

Hasil audiometri berdasarkan jenis kelamin di tunjukan oleh Tabel 3.

Tabel 3. Hasil audiometri berdasarkan jenis kelamin.

\begin{tabular}{|c|c|c|c|c|c|}
\hline $\begin{array}{l}\text { Jenis } \\
\text { kelamin }\end{array}$ & $\begin{array}{l}\text { Tuli } \\
\text { Ringan }\end{array}$ & $\begin{array}{l}\text { Tuli } \\
\text { Sed } \\
\text { ang }\end{array}$ & $\begin{array}{l}\text { Tu } \\
\text { li } \\
\text { Be } \\
\text { rat }\end{array}$ & Normal & Total \\
\hline Laki-laki & $6(30 \%)$ & $\begin{array}{l}1(5 \\
\%)\end{array}$ & 0 & $9(45 \%)$ & $16(80 \%)$ \\
\hline $\begin{array}{l}\text { Perempua } \\
\mathrm{n}\end{array}$ & $1(5 \%)$ & 0 & 0 & $3(15 \%)$ & $4(20 \%)$ \\
\hline Total & & & & & $20(100 \%)$ \\
\hline
\end{tabular}

Dari Tabel 2, terlihat bahwa gangguan pendengaran terbanyak adalah laki-laki dengan tuli ringan sebesar $30 \%$ dan tuli sedang 5\% karena pekerja laki-laki yang banyak di periksa. Beberapa penelitian menunjukan bahwa laki-laki lebih rentan terhadap gangguan pendengaran di bandingkan perempuan. Penelitian yang di lakukan oleh Third National Health and Nutrition Examination Survey ( NHANES III ), menunujukan bahwa wanita lebih rendah kemungkinan terkena gangguan pendengaran frekuensi tinggi di bandingkan laki-laki. ${ }^{22}$

Hasil audiometri berdasarkan usia di tunjukan oleh Tabel 4.

Tabel 4. Hasil audiometri berdasarkan usia pekerja.

\begin{tabular}{llllll}
\hline Usia & $\begin{array}{l}\text { Tuli } \\
\text { Ringan }\end{array}$ & $\begin{array}{l}\text { Tuli } \\
\text { Sedan } \\
\text { g }\end{array}$ & $\begin{array}{l}\text { Tuli } \\
\text { Ber } \\
\text { at }\end{array}$ & $\begin{array}{l}\text { Norm } \\
\text { al }\end{array}$ & Total \\
\hline $\begin{array}{l}<20 \\
\text { tahun }\end{array}$ & 0 & $1(5 \%)$ & 0 & $1(5 \%)$ & $2(10 \%)$ \\
$21-24$ & $5(25 \%)$ & 0 & 0 & $\begin{array}{l}10(50 \\
\%)\end{array}$ & $15(65 \%)$ \\
tahun & & & & $1(5 \%)$ & $3(15 \%)$ \\
$\begin{array}{l}25-30 \\
\text { tahun }\end{array}$ & $2(10 \%)$ & 0 & 0 & & $\mathbf{2 0 ( 1 0 0 \% )}$ \\
\hline Total & & & & & \\
\hline
\end{tabular}

Dari Tabel 3 Di temukan paling banyak antara usia 21-24 taun yaitu sebanyak 5 responden dan sebesar 25\%. Usia berperan dalam kerentanan seseorang terhadap paparan akustik terhadap telinga. Insiden gangguan pendengaran pada usia di atas 40 tahun lebih tinggi terjadi gangguan pendengaran, oleh karena faktor lain seperti kemampuan pendengaran yang semakin menurun. ${ }^{23}$

Hasil ini mungkin dapat menjelaskan mengapa pada sampel yang di teliti ini, gangguan pendengaran yang di alami lebih banyak bersifat ringan, karena kebanyakan sampel yang di periksa berusia lebih muda.

Hasil audiometri berdasarkan lama kerja di tunjukan oleh Tabel 5.

Tabel 5. Hasil audiometri berdasarkan lama kerja.

\begin{tabular}{|c|c|c|c|c|c|}
\hline $\begin{array}{l}\text { Lama } \\
\text { kerja }\end{array}$ & $\begin{array}{l}\text { Tuli } \\
\text { Ringa } \\
\text { n }\end{array}$ & $\begin{array}{l}\text { Tuli } \\
\text { Sedan } \\
\text { g }\end{array}$ & $\begin{array}{l}\text { Tuli } \\
\text { Berat }\end{array}$ & $\begin{array}{l}\text { Nor } \\
\text { mal }\end{array}$ & Total \\
\hline $\begin{array}{l}2-4 \\
\text { bulan }\end{array}$ & $1(5 \%)$ & 0 & 0 & $\begin{array}{l}4(20 \\
\%)\end{array}$ & $5(25 \%)$ \\
\hline $\begin{array}{l}5-7 \\
\text { bulan }\end{array}$ & $\begin{array}{l}3(15 \% \\
)\end{array}$ & 0 & 0 & $\begin{array}{l}8(40 \\
\%)\end{array}$ & $11(55 \%)$ \\
\hline $\begin{array}{l}>1 \\
\text { tahun }\end{array}$ & $\begin{array}{l}3(15 \% \\
)\end{array}$ & 1(5\%) & 0 & 0 & $4(20 \%)$ \\
\hline Total & & & & & $00 \%)$ \\
\hline
\end{tabular}

Dari Tabel 5 Menunujukan bahwa lama kerja sangat mempengaruhi kejadian gangguan pendengaran pada pekerja hiburan malam. Terlihat lama kerja 5-7 bulan sebesar $15 \%$ sedangkan lama kerja $>1$ tahun sebanyak 4 responden, dan semuanya mengalami tuli ringan atau sedang.

Data di atas menunjukan bahwa paparan yang lama terhadap kebisingan memberikan kemungkinan kerusakan lebih besar di bandingkan dengan waktu paparan yang lebih singkat, walaupun tidak terdapat perbedaan yang signifikan. ${ }^{23}$

\section{SIMPULAN DAN SARAN}

Pada penelitian ini dapat di ambil kesimpulan, dari 20 responden pekerja 
hiburan malam, terdapat 8 responden mengalami gangguan pendengaran (40\%), mulai dari gangguan ringan 7 responden (35\%), dan gangguan pendengaran sedang 1 responden (5\%). Usia pekerja hiburan malam, paling banyak antara usia 21-24 tahun yaitu sebanyak 5 responden atau sebesar (25\%).

Lama kerja sangat mempengaruhi kejadian gangguan pendengaran pada pekerja hiburan malam, lama kerja 5-7 bulan sebesar (15\%) sedangkan lama kerja $>1$ tahun sebanyak 4 responden atau sebesar (20\%), dan semuanya mengalami tuli sedang atau ringan.

Saran pada penelitian ini, bahwa pekerja hiburan malam harus menggunakan alat pelindung telinga, agar mengurangi kemungkinan gangguan pendengaran, lama kerja pada tingkat kebisingan di atas $85 \mathrm{~dB}$ dapat di singkat.

Perlu dilakukan penelitian dengan jumlah responden yang lebih besar untuk menemukan perbedaan gangguan pendengaran, diantara pekerja hiburan malam.

\section{DAFTAR PUSTAKA}

1. Mathur NN., Meyer AD., et.al. Noiseinduced hearing loss. Medscape refference. April, 2012.
2. Shah RK., Isaacson GC. Et.al. Hearing impairment. Medscape refference. July, 2011.

3. Irwin J. Occupational of noise-induced hearing loss. Clinical assesment in the workplace. Occupational medicine. Ninewells hospital, Dundee, DD1 9SY, Scotland. Vol. 47, No. 5.p 313-315

4. Kirchner DB., Evenson CE., Dobie RA., et al. Occupational noise-induced hearing loss. ACOEM Task Force on Occupational Hearing Loss. In: ACOEM guidance statement. 2012:54(1):106-8.

5. OSHA's Hearing Conservation Amendment CFR 1910.95.” National Hearing Conservation Association. 2010

6. Levey S., Fligor BJ., Ginocchi C., Kagimbi L. The effect of noise-induced hearing loss on children and young adults. In: Contemporary issues in Communication science and disorder. 2012:39:76-83

7. Shargorodsky J., et all. Change in prevalence of hearing loss in US Adolescents. Journal of American Medical Association. Vol 304. No 7. 2010

8. Safe work Australia. Managing noise and preventing hearing loss. Code of Practice. NSW government, 2011

9. Bhatt R.E., Gest T.R. Ear anatomy. Medscape Refference. Sept. 2013

10. Wedro BC, Shiel BC. Hearing and balance anatomy. Medicine net. 2013 